\title{
Protein Kinase Activity and Endogenous Protein Phosphorylation in Rat Liver Plasma Membranes
}

\author{
MARIANNE SOMMARIN, THOMAS HENRIKSSON and BENGT JERGIL
}

Biochemistry 1, Chemical Centre, P.O. Box 740, S-220 07 Lund, Sweden.

When rat liver plasma membranes were incubated with $\left[\gamma^{32} \mathrm{P}\right]$ ATP radio-labelled phosphate was incorporated into endogenous protein and exogenous substrate by a membrane-bound protein kinase activity. A high ATP/membrane protein ratio was required for optimum incorporation conditions. Cyclic AMP did not affect the incorporation of phosphate. The protein kinase activity was extracted from the membranes by $1 \%$ Triton $\mathrm{X}-100$ and a high concentration of $\mathrm{KCl}$. The solubilised enzyme resolved into two fractions on DEAE-cellulose chromatography. One enzyme fraction had the same properties as the catalytic subunit of cytosolic cyclic AMP-dependent protein kinases. Endogenously phosphorylated proteins were resolved by SDS-polyacrylamide gel electrophoresis into five major and additional minor phosphorylated components. Three of the major phosphorylated components were tightly bound to the membrane material and were not extracted by $1 \%$ Triton $\mathrm{X}-100$ and $1 \mathrm{M} \mathrm{KCl}$.

The activity of several proteins is regulated by enzymically catalysed phosphorylation-dephosphorylation reactions. ${ }^{1}$ Protein phosphorylation in rat liver is a feature of most subcellular fractions, ${ }^{2-4}$ and protein kinases have been isolated and characterised from the cytosol, ${ }^{3,5,6}$ microsomes, ${ }^{3}$ mitochondria ${ }^{7-9}$ and nuclei. ${ }^{10,11}$ Comparatively little is known about protein kinases and the phosphorylation of proteins in rat liver plasma membranes. Early studies by Blat and Harel ${ }^{12}$ showed that $\left[{ }^{32} \mathrm{P}\right]$ phosphate was incorporated into proteins of such membranes in vivo, and that isolated plasma membranes catalysed the incorporation of phosphate from $\left[\gamma-{ }^{32} \mathrm{P}\right]$ ATP into endogenous proteins. ${ }^{13}$ Apparently, partially purified protein kinase from rat liver cytosol also catalyses the phosphorylation of plasma membrane proteins. ${ }^{14}$
We have previously examined protein phosphorylation, protein kinases and phosphoproteins in rat liver membrane fractions including microsomes and mitochondria. ${ }^{3,4,9}$ Our investigations have now been extended to plasma membranes.

\section{EXPERIMENTAL}

Chemicals. $\left[{ }^{32} \mathrm{P}\right]$-Inorganic phosphate was obtained from the Radiochemical Centre (Amersham). $\left[\gamma-{ }^{32}\right.$ P] ATP was synthesised according to Chang et al. ${ }^{13}$ Protamine sulfate, calf thymus histones (Type II-A) and rabbit muscle protein kinase inhibitor were from Sigma, adenosine deaminase from Boehringer, acrylamide from Bio-Rad, and $N, N^{\prime}$-methylene bisacrylamide (which was recrystallised twice from acetone) from Eastman. All other chemicals were of reagent grade.

Preparation of plasma membranes. Male SpragueDawley rats fed ad libitum were stunned by a blow on the head and bled by cutting the carotic artery. Livers were excised immediately and chilled at $0{ }^{\circ} \mathrm{C}$ in $5 \mathrm{mM}$ Tris $-\mathrm{HCl}, \mathrm{pH} 8.0,0.25 \mathrm{M}$ sucrose and $0.1 \mathrm{mM}$ dithioerythritol. All subsequent preparations were at $0-4^{\circ} \mathrm{C}$.

Plasma membranes were prepared according to Aronson and Touster. ${ }^{16}$ The $\mathrm{N}_{2}$ fraction, which was less contaminated by other membranes than the $\mathbf{P}_{2}$ fraction as based on marker enzyme analyses, was used. The average relative specific activities of marker enzymes in several preparations of the $\mathbf{N}_{2}$ fraction compared to the tissue homogenate were 34 for $5^{\prime}$-nucleotidase (measured by method 3 in Ref. 17); 0.3 for lactate dehydrogenase, ${ }^{18} 0.03$ for cytochrome oxidase (measured as described in Ref. 19 but using an extinction coefficient of $21 \mathrm{mM}^{-1}$ $\left.\mathrm{cm}^{-1}\right) ; 201.0$ for NADPH-cytochrome $c$ reductase; ${ }^{20}$ and 6.0 for $N$-acetylglucosamine galactosyltransferase. $^{21}$ 
Analyses. Protein kinase activity and endogenous phosphorylation were assayed as described earlier ${ }^{22,23}$ with the following modifications. The protein kinase assay mixture contained $2 \mathrm{mM}$ $\left[\gamma-{ }^{32} \mathrm{P}\right]$ ATP $(50000-100000 \mathrm{dpm} / \mathrm{nmol})$ and $3 \mu \mathrm{g}$ of membrane protein in a final volume of $50 \mu \mathrm{l}$ unless otherwise stated, and the incubation time was $1 \mathrm{~min}$ at $25^{\circ} \mathrm{C}$. Endogenous phosphorylation was determined in a medium containing $2 \mathrm{mM}$ $\left[\gamma^{32}\right.$ P $]$ ATP $(50000-100000 \mathrm{dpm} / \mathrm{nmol}), 20 \mathrm{mM}$ sodium azide and $20 \mu \mathrm{g}$ of protein in a final volume of $50 \mu$ l. The incubation time was $5 \mathrm{~min}$ at $25^{\circ} \mathrm{C}$. In the time course experiments the reaction mixture was scaled-up and samples $(50 \mu \mathrm{l})$ were withdrawn at indicated times.

Substrate specificity was examined using protamine or a histone mixture as substrate. ${ }^{23}$ Protamine phosphorylation was examined in the presence and absence of $0.3 \mathrm{M} \mathrm{NaCl}$, and the phosphorylation of histones in the absence of salt. The amount of histone was $0.6 \mathrm{mg}$ per $100 \mu \mathrm{l}$ of incubation mixture.

The inhibition of protein kinase activity by protein kinase inhibitor ${ }^{24}$ was studied using a fixed amount of enzyme and increasing the concentrations of the inhibitor. The activity was assayed in the presence of $10 \mu \mathrm{M}$ cyclic AMP using protamine as a substrate.

Isoelectric focusing was as described previously. ${ }^{3}$ Protein was measured by the Lowry method ${ }^{25}$ after precipitation with $10 \%$ trichloroacetic acid. Bovine serum albumin was used as a standard. All determinations were in duplicate.

Extraction of protein kinase from plasma membranes. For extraction experiments plasma membranes were incubated with 0.3 or $1 \mathrm{M} \mathrm{KCl}$ in the presence or absence of $1 \%$ Triton $X-100$. After incubation for $30 \mathrm{~min}$ at $0{ }^{\circ} \mathrm{C}$ samples were centrifuged at $105000 \times g$ for $90 \mathrm{~min}$. The supernatants and pellets resuspended in buffer $(10 \mathrm{mM}$ Tris- $\mathrm{HCl}, \mathrm{pH} 8.0,1 \mathrm{mM} \mathrm{MgCl}, 0.1 \mathrm{mM}$ dithioerythritol) were analysed for protein kinase, endogenous incorporation of phosphate, $5^{\prime}$-nucleotidase and protein content.

DEAE-cellulose chromatography. Plasma membranes were extracted in $1 \%$ Triton $X-100$ and $1.0 \mathrm{M} \mathrm{KCl}$ as described above. The extract was dialysed extensively against $10 \mathrm{mM}$ Tris $-\mathrm{HCl}$, pH 7.4, $1 \mathrm{mM} \mathrm{MgCl}_{2}$ and $0.1 \mathrm{mM}$ dithioerythritol. The dialysed extract was applied onto a DEAEcellulose (Whatman DE-52) column and the chromatography was developed with a linear $\mathrm{KCl}$ gradient. ${ }^{3}$ The eluate was analysed for protein kinase activity using $0.5 \mathrm{mM}\left[\gamma-{ }^{32} \mathrm{P}\right] \mathrm{ATP}$ and protamine sulfate as a substrate. ${ }^{2 \gamma}$

SDS-polyacrylamide gel electrophoresis. Endogenous phosphorylation for electrophoresis was with $20-100 \mu \mathrm{g}$ of membrane protein as described above using $\left[\gamma^{32} \mathrm{P}\right]$ ATP with a specific activity of $0.8 \times 10^{6} \mathrm{dpm} / \mathrm{nmol}$. Electrophoresis was according to Neville ${ }^{26}$ with some modifications. ${ }^{9}$ The further treatment of the gels and autoradiography have been described previously. ${ }^{9}$ The following standard proteins were used: bovine serum albumin, $M_{\mathrm{r}}$ 69000 ; ovalbumin, $M_{\mathrm{r}} 45000$; soybean trypsin inhibitor, $M_{\mathrm{r}} 21500$; and sperm whale myoglobin, $M_{\mathrm{r}} 17200$.

\section{RESULTS}

Time course of protein kinase activity and endogenous phosphorylation. In initial experiments we found that purified plasma membranes from rat liver catalysed the incorporation of phosphate from ATP into protamine and that there was also incorporation into endogenous substrates. These experiments further indicated that a much higher ATP/membrane protein ratio was required in plasma membranes than in other membranes from rat liver cells to obtain optimum conditions for the incorporation of phosphate into both exogenous and endogenous substrates.

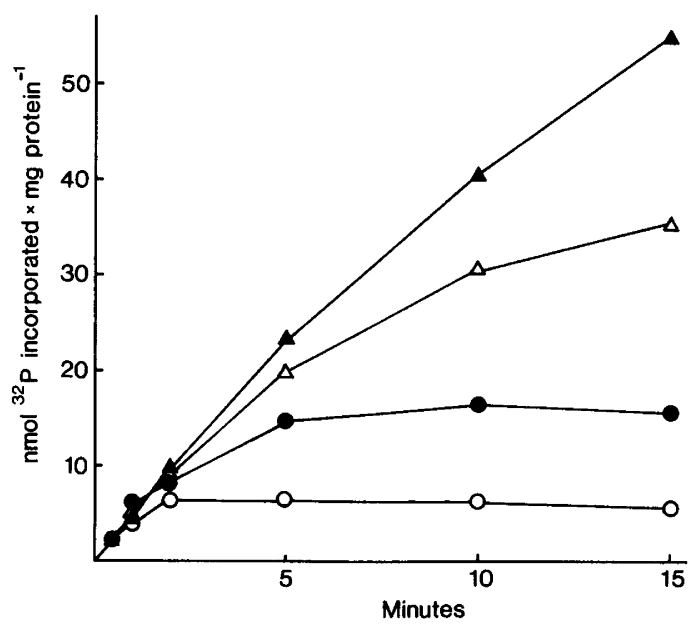

Fig. 1. Time course of plasma membrane protein kinase activity. Plasma membranes $(3$ or $20 \mu \mathrm{g}$ of membrane protein per $50 \mu$ lincubation mixture) were incubated with protamine as exogenous substrate as described under Experimental, and the incorporation into trichloroacetic acid-sodium tungstate precipitable phosphate was determined. Analyses were performed in presence (closed symbols) or absence (open symbols) of $20 \mathrm{mM}$ sodium azide. $\Delta, 3 \mu \mathrm{g}$ of membrane protein; $\bigcirc, 20 \mu \mathrm{g}$ of membrane protein. 


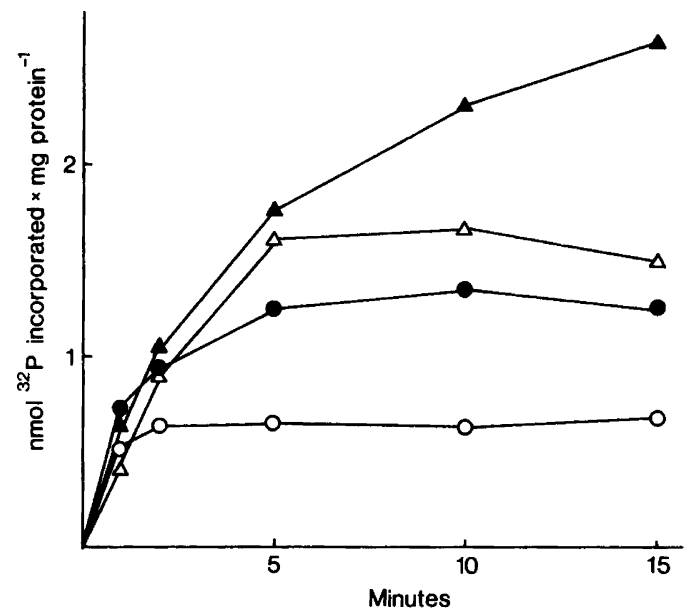

Fig. 2. Time course of endogenous incorporation of phosphate into plasma membranes. Incubations were performed as described under Experimental, and the incorporation of phosphate into trichloroacetic acid-sodium tungstate precipitable material was determined. Symbols represent the same amounts of plasma membranes and sodium azide as in Fig. 1.

The time courses of plasma membrane protein kinase activity obtained with various amounts of membrane protein and $2 \mathrm{mM}$ ATP are presented in Fig. 1. The effect of the ATPase inhibitor sodium azide was also tested. The rate of incorporation was linear for $2 \mathrm{~min}$ at a low membrane protein concentration ( $3 \mu \mathrm{g}$ per $50 \mu \mathrm{l}$ incubation medium) and then decreased slowly. At $20 \mu \mathrm{g}$ the incorporation levelled off already after $2 \mathrm{~min}$. This was probably due to exhaustion of ATP caused primarily by membrane ATPase, since the reaction proceeded for a longer time in the presence of azide. In comparison, when the incubation conditions used earlier for microsomes and mitochondria ${ }^{3,9}$ were tested with plasma membranes the incorporation ceased within $20 \mathrm{~s}$.

The endogenous incorporation of phosphate into plasma membranes followed similar time courses as the protein kinase activity (Fig. 2), although the initial reaction rate was 10 times lower than with exogenous substrate. At the low membrane concentration, maximum incorporation was reached after $5 \mathrm{~min}$ with $1.6 \mathrm{nmol}$ of phosphate incorporated per $\mathrm{mg}$ of membrane protein. Further incorporation was obtained in the presence of azide. Cyclic

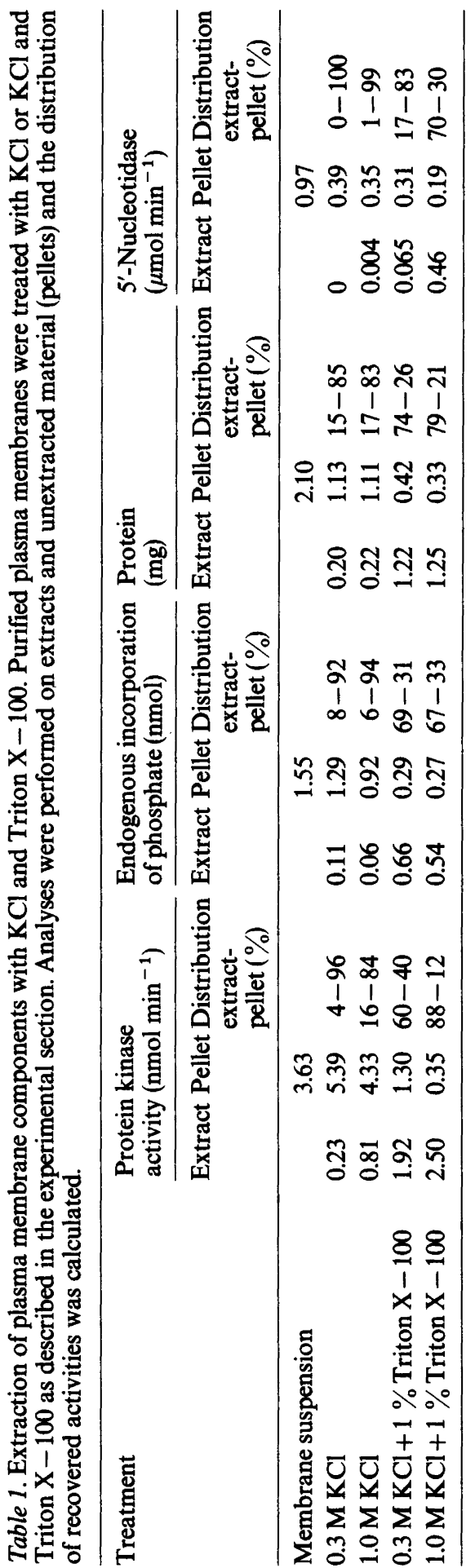


AMP did not stimulate the phosphorylation of either endogenous or exogenous substrates.

Extraction of protein kinase from plasma membranes. To examine how tightly the protein kinase activity was attached to the membranes, extraction experiments were performed. Isolated plasma membranes were treated with various $\mathrm{KCl}$ and Triton $\mathrm{X}-100$ concentrations and the distribution of protein kinase, endogenous phosphorylation, protein and the plasma membrane marker enzyme 5'-nucleotidase between solubilised and residual material was measured (Table 1). No 5'-nucleotidase activity and only a small fraction of protein kinase, endogenously phosphorylated material and protein was released from the plasma membranes on treatment with $0.3 \mathrm{M}$ or $1 \mathrm{M} \mathrm{KCl}$. However, a major part of protein kinase activity, endogenously phosphorylated material and protein was extracted in the presence of both salt and Triton X-100. The bulk of the protein appeared to be extracted under less drastic conditions than the protein kinase, since the protein was released at lower concentrations of Triton X-100 than most of the protein kinase activity (not shown). Most of the 5 '-nucleotidase activity remained in the particulate fraction at 0.3 $\mathrm{M} \mathrm{KCl}$ and $1 \%$ Triton X-100, but was released when the salt concentration was increased to $1 \mathrm{M}$ in presence of the detergent.

The protein kinase activity of plasma membranes increased by approximately $50 \%$ on treatment with $\mathrm{KCl}$. The recovery of protein kinase after detergent treatment was lower, however, than the activity present in the parent membrane suspension. This is in contrast to what we have found earlier in microsomes and mitochondria where the protein kinase activity was latent in the membrane and increased several-fold in the presence of Triton $\mathrm{X}-100 .{ }^{3,9}$

DEAE-cellulose chromatography. Plasma membranes were treated with $1 \%$ Triton X-100 and $1 \mathrm{M}$ $\mathrm{KCl}$, and the solubilised material was subjected to DEAE-cellulose chromatography. Two peaks (PM I and PM II) with protein kinase activity were resolved (Fig. 3). When eluted from the column none of these peaks was stimulated by cyclic AMP. The two peaks eluted at the same salt concentrations $(0.03$ and $0.20 \mathrm{M}$, respectively) as two (M I and $M$ III) of the three protein kinase peaks from rat liver microsomes ${ }^{3}$ and rat liver mitochondria. ${ }^{9}$ Two protein kinases that elute under these conditions have also been found in rat liver cytosol, which, in addition, contains two other enzyme peaks. ${ }^{3}$ Occasionally a third plasma membrane protein kinase fraction was observed which eluted at the same $\mathrm{KCl}$ concentration $(0.14 \mathrm{M})$ as the $\mathrm{M}$ II fraction of microsomes and mitochondria.

Characterisation of the protein kinase fractions. Analyses of the protein kinase peaks from microsomes and the cytosol ${ }^{3}$ have shown that the first eluting peak is the catalytic subunit of the cyclic

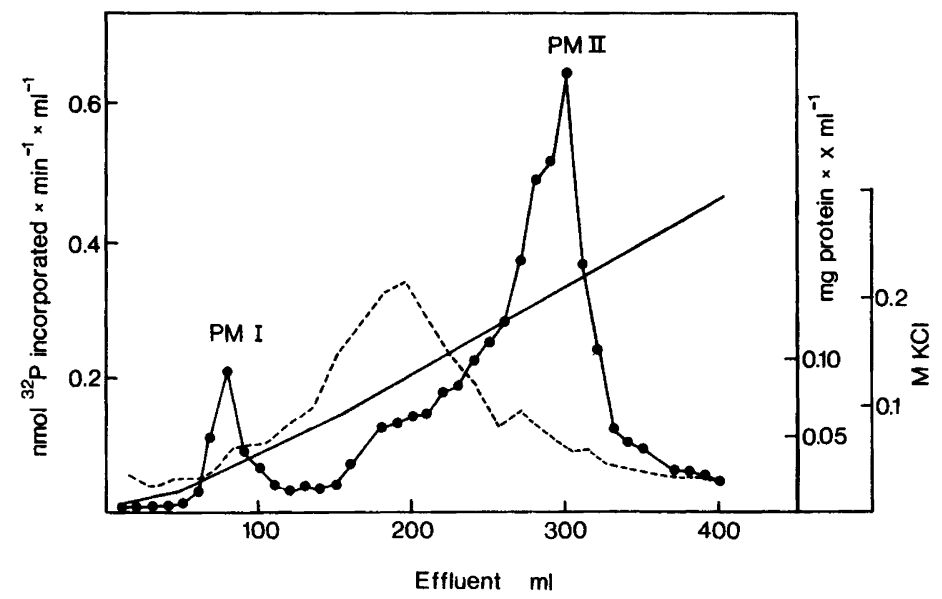

Fig. 3. DEAE-cellulose chromatography of plasma membrane protein kinase activity. Conditions used were as described in the experimental section. Protein kinase activity $(\bullet)$ was determined with protamine as substrate. ---, protein concentration measured according to Lowry;,$- \mathrm{KCl}$ gradient. The applied amount of protein was $15 \mathrm{mg}$. 
Table 2. Substrate specificity of protein kinases and activity in presence of protein kinase inhibitor. Protein kinases were isolated from plasma membranes and cytosol by DEAE-cellulose chromatography. Their substrate specificities were determined in presence of $5 \mu \mathrm{M}$ cyclic AMP. The designations of the cytosolic protein kinases are the same as in Ref. 3. Activities are expressed relative to the activity towards protamine in presence of $0.3 \mathrm{M} \mathrm{NaCl}$. The activity with protein kinase inhibitor was determined under conditions of maximum inhibition with protamine as substrate.

\begin{tabular}{|c|c|c|c|c|c|c|}
\hline \multirow[t]{2}{*}{ Substrate } & \multicolumn{2}{|c|}{$\begin{array}{l}\text { Plasma membrane } \\
\text { protein kinase }\end{array}$} & \multicolumn{4}{|c|}{ Cytosolic protein kinase } \\
\hline & PM I & PM II & CI & C IIa & C IIb & C III \\
\hline $\begin{array}{l}\text { Protamine }+\mathrm{NaCl} \\
\text { Protamine }-\mathrm{NaCl} \\
\text { Histone mixture } \\
\text { Activity with protein kinase inhibitor }\end{array}$ & $\begin{array}{r}100 \\
42 \\
18 \\
14\end{array}$ & $\begin{array}{r}100 \\
106 \\
9 \\
70\end{array}$ & $\begin{array}{r}100 \\
41 \\
7 \\
24\end{array}$ & $\begin{array}{r}100 \\
41 \\
9 \\
27\end{array}$ & $\begin{array}{r}100 \\
90 \\
4 \\
97\end{array}$ & $\begin{array}{r}100 \\
77 \\
12 \\
52\end{array}$ \\
\hline
\end{tabular}

AMP dependent protein kinases, the second peak is a cyclic AMP independent enzyme while the third peak is the cyclic AMP dependent type $\mathrm{II}^{27}$ protein kinase. Isoelectric focusing of PM I showed that this peak had the same isoelectric point $(\mathrm{pI}=8.1)$ as the catalytic subunit isolated from the cytosol. ${ }^{3}$ Although the PM II fraction was unstable on isoelectric focusing (the recovery was $2 \%$ compared to $25-40 \%$ obtained for other protein kinases examined in this manner) two protein kinase peaks could be observed with the isoelectric points 5.5 and 4.9. These correspond to the pI values we obtained earlier with the cyclic AMP-independent protein kinase and the cyclic AMP-dependent type II enzyme, respectively. ${ }^{3}$

The PM I and PM II protein kinase fractions were characterised further by their substrate specificity (of particular interest was the influence of $\mathrm{NaCl}$ on the phosphorylation of protamine) and the effect of a protein kinase inhibitor isolated from rabbit skeletal muscle (Table 2). Both substrate specificity and maximum inhibition by the protein kinase inhibitor were similar for PM I and the cytosolic protein kinase fraction C I (for designations of cytosolic kinases, see Ref. 3), providing further evidence that PM I is the catalytic subunit of cyclic AMP-dependent protein kinases. The activity of the PM II fraction decreased $30 \%$ in the presence of inhibitor, and the rate of protamine phosphorylation by this enzyme was independent of the concentration of $\mathrm{NaCl}$. In comparison, the decrease in activity of the cyclic AMP-dependent cytosolic protein kinases C IIa and C III due to the presence of inhibitor was 73 and $48 \%$, respectively, while the cyclic AMP-independent enzyme C IIb was unaffected. The lower inhibition of fraction C III compared to C IIa was probably due to an incomplete dissociation of the holoenzyme under the experimental conditions used. The phosphorylation of protamine catalysed by fraction $\mathrm{C} \mathrm{IIb}$ was also unaffected by $0.3 \mathrm{M} \mathrm{NaCl}$, while the usual stimulation by salt was observed for the cyclic AMP-dependent enzyme fractions. The rate of histone phosphorylation was similar for the different enzyme fractions.

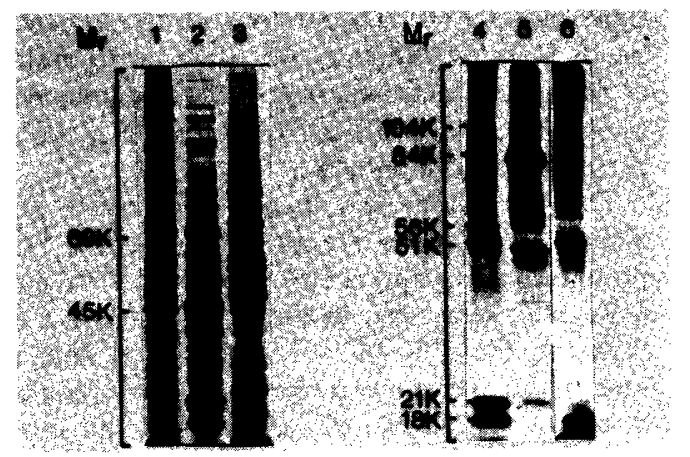

Fig. 4. Protein and phosphoprotein patterns of plasma membranes (lane 1 and 4), cytosol (2 and 5) and smooth microsomes ( 3 and 6$)$ from rat liver. $1-3$, protein patterns; $4-6$, phosphoprotein patterns obtained by autoradiography. Standard proteins are indicated to the left of lane 1 and the apparent $M_{\mathrm{r}}$ of phosphorylated components to the left of lane 4. The protein patterns are from a different run than the phosphoprotein patterns. Smooth microsomes and cytosol were prepared as previously described. $^{3}$ 
Phosphoprotein and protein patterns. To examine phosphoprotein and protein patterns, plasma membranes were phosphorylated endogenously using $\left[\gamma-{ }^{32} \mathrm{P}\right]$ ATP followed by SDS - polyacrylamide gel electrophoresis and autoradiography. For a comparison we also examined smooth endoplasmic reticulum and cytosol from rat liver in the same way. The protein patterns of plasma membranes, smooth microsomes and cytosol were distinctly different (Fig. 4), indicating that plasma membranes were not seriously contaminated by the latter two fractions. The phosphoprotein patterns were also different. Five prominent phosphorylated components (labelled $84 \mathrm{~K}, 56 \mathrm{~K}, 51 \mathrm{~K}, 21 \mathrm{~K}$, and $18 \mathrm{~K}$ in the figure after their apparent $M_{\mathrm{r}}$ ) and additional minor ones were resolved from plasma membranes. Three of the major components seemed to be unique to plasma membranes while one $(21 \mathrm{~K})$ had the same mobility as a phosphorylated component in the cytosol and another (18K) the same as one of the microsomal components. The $18 \mathrm{~K}$ and $21 \mathrm{~K}$ components remain unidentified so far, and it is not known whether they represent proteins present in more than one subcellular fraction, or whether they fortuitously have the same mobility as unrelated phosphorylated proteins in microsomes or the cytosol.

The phosphoprotein pattern of plasma membranes was also examined after various incubation times (not shown). The strength of all radioactive bands increased similarly when the incorporation of phosphate increased indicating a simultaneous phosphorylation of the components under the experimental conditions used.

The phosphoprotein patterns obtained after different extractions are shown in Fig. 5. Four prominent phosphorylated components $(59 \mathrm{~K}, 49 \mathrm{~K}$, $41 \mathrm{~K}, 39 \mathrm{~K}$ ) were seen in the $1 \mathrm{M} \mathrm{KCl}$-extract. Of these the $59 \mathrm{~K}, 49 \mathrm{~K}$ and $39 \mathrm{~K}$ components were not seen in the parent membrane, while the $41 \mathrm{~K}$ component was a minor phosphorylated band in the native membrane which became heavily phosphorylated after extraction. Additional phosphoprotein bands (104K and $51 \mathrm{~K})$ were seen in the $\mathrm{KCl}$ and Triton $\mathrm{X}-100$ extract. Interestingly, the $56 \mathrm{~K}, 51 \mathrm{~K}$ (in part) and $21 \mathrm{~K}$ components remained in the particulate fraction after this drastic treatment which removed $80 \%$ of the membrane proteins, while the $18 \mathrm{~K}$ component was found neither in the extract nor in the pellet.

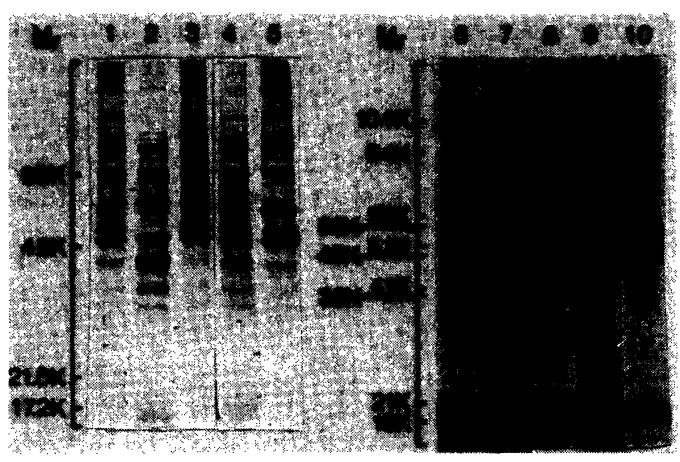

Fig. 5. Protein and phosphoprotein patterns of plasma membranes after various extractions. Extractions were performed with $1 \mathrm{M} \mathrm{KCl}$ or $1 \%$ Triton X-100 and $1 \mathrm{M} \mathrm{KCl}$ as described in the experimental section. Extracts and residues were phosphorylated endogenously before electrophoresis and autoradiography. $1-5$ are protein patterns and 6-10 are phosphoprotein patterns in the order plasma membranes, $\mathrm{KCl}$ extract, residue after $\mathrm{KCl}$ extraction, Triton $\mathrm{X}-100+\mathrm{KCl}$ extract, residue after Triton $\mathrm{X}-100+\mathrm{KCl}$ extraction. Standard proteins are indicated to the left of lane 1 and the apparent $M_{\mathrm{r}}$ of phosphorylated components to the left of lane 6 .

\section{DISCUSSION}

Several pieces of evidence indicate that the isolated protein kinases and phosphoproteins are harboured in the plasma membrane rather than representing contamination from other subcellular fractions. First, plasma membranes were substantially enriched during the preparation compared to other subcellular fractions (for instance, they were enriched 35-fold as compared to microsomal membranes). Second, both protein and phosphoprotein patterns were unique to the plasma membrane fraction. Third, no latency of protein kinase activity was observed when plasma membrane were treated with Triton X-100. In comparison, there is a several-fold increase in the kinase activity upon treatment of microsomes, ${ }^{3}$ mitochondria ${ }^{9}$ or Golgi membranes (unpublished) with the detergent. Furthermore, the protein kinases appeared to be tightly bound to the membrane, since a rather harsh treatment with detergent and a high salt concentration were required to solubilise the enzyme activity.

Cyclic AMP did not stimulate the membraneassociated or solubilised kinase when analysed with 
either endogenous or exogenous substrates, contrary to what has been found for plasma membrane protein kinases from other kinds of cells. ${ }^{28,29} \mathrm{We}$ observed, however, that cyclic AMP-binding material is present in liver plasma membranes (approximately 2 pmol cyclic AMP bound per $\mathrm{mg}$ of membrane protein). This material has not been further characterised and it is unclear whether it represents any of the regulatory subunits of cyclic AMP-dependent protein kinases or other cyclic AMP-binding components.

The specific activity of the protein kinase of plasma membranes was several-fold higher than in microsomes ${ }^{3}$ or mitochondria. ${ }^{9}$ However, the enzyme activity of plasma membranes did not show any latency on detergent treatment in contrast to the activity in microsomes or the mitoplast fraction of mitochondria. The lack of latency indicates that the substrate (protamine) is freely accessible to the protein kinase. Since we have found in preliminary experiments that only a few proteins in isolated plasma membranes become significantly labelled by diazotised iodosulfanilic acid, all membranes probably expose the same surface to the surrounding medium. The protein kinase may therefore be attached to only one plasma membrane surface in intact cells. This is likely to be the outer surface. ${ }^{30,31}$ It has been reported that protein kinases are exposed on the outer surface of various kinds of cells including adipocytes ${ }^{32}$ and Ehrlich ascites tumour cells. ${ }^{33}$

The protein kinase of plasma membranes was resolved into two enzymically active fractions on DEAE-cellulose chromatography. The first eluting fraction (PM I) is likely to represent the catalytic subunit of cyclic AMP-dependent protein kinases based on its isoelectric point, its substrate specificity and its inhibition by the protein kinase inhibitor. We have found earlier that the catalytic subunit apart from being present in the cytosol is also present in small amounts in rat liver microsomes ${ }^{3}$ and mitochondria. ${ }^{9}$ The subunit therefore seems to be widely distributed in the cell. The possibility that it is a contaminant from the cytosol appears less likely since a cytosolic enzyme as lactate dehydrogenase was present in a very low concentration in purified plasma membranes and since drastic conditions were required to solubilise protein kinase from the membrane.

The identity of the second kinase fraction (PM II) is less clear. It eluted from DEAE-cellulose at the same $\mathrm{KCl}$ concentration as the cyclic AMP- dependent type II protein kinase which also seems to be present in microsomes and mitochondria., The PM II fraction was partly inhibited by the protein kinase inhibitor, but contrary to what is expected for cyclic AMP-dependent protein kinases, ${ }^{3} \mathrm{NaCl}$ did not activate the phosphorylation of protamine by this fraction. Furthermore, the enzyme activity was unaffected by cyclic AMP when eluted from the column. However, a stimulation by this nucleotide is not necessarily expected with such a dilute enzyme as in this case (cf. Ref. 9). Due to the lability of the enzyme we have not yet been able to perform detailed studies of its properties.

Only a few proteins became heavily phosphorylated on endogenous phosphorylation of isolated plasma membranes. Most of these phosphoproteins were tightly bound to the particulate material since they were not released by treatment of the membrane with detergent and high $\mathrm{KCl}$ concentrations. Some proteins which were not phosphorylated significantly in the isolated membrane were amenable to phosphorylation after treatment with $\mathrm{KCl}$ and/or detergent. It is possible therefore that there are restrictions in enzyme-substrate interactions in the isolated membrane, either due to different transverse locations of enzymes and substrates, or to restrictions in their lateral mobility. If some protein substrates are located on the inner surface of intact cells while protein kinases are located on the outside, these substrates may be available for phosphorylation only by cytosolic protein kinases. We are presently studying the transverse location of protein kinases and their substrates in plasma membranes to resolve these questions.

As to the biochemical significance of protein phosphorylation in rat liver plasma membranes, one can only speculate as long as the phosphoproteins remain unidentified. Since protein phosphorylation in general seems to be connected with various regulatory functions in the cell, it is likely that the phosphorylation of proteins in plasma membranes also is a regulatory device. Thus, it has been suggested that the state of protein phosphorylation in erythrocyte membranes may regulate the membrane structure,,$^{34}$ and there is indirect evidence for a correlation between protein phosphorylation and the movement of $\mathrm{Na}^{+}$ions through the erythrocyte membrane. $^{35}$ There is also a recent report ${ }^{36}$ on protein kinase-catalysed phosphorylation of the $\mathrm{Na}^{+}, \mathrm{K}^{+}$-ATPase of kidney plasma membranes. 
Acknowledgement. This work was supported by grants from the Swedish Natural Science Research Council.

\section{REFERENCES}

1. Weller, M. Protein phosphorylation. The nature, function, and metabolism of proteins which contain covalently bound phosphorus, Pion Ltd, London 1979.

2. Zahlten, R. N., Hochberg, A. A., Stratman, F. W. and Lardy, H. A. Proc. Natl. Acad. Sci. U.S.A. 69 (1972) 800.

3. Sommarin, M. and Jergil, B. Eur. J. Biochem. 88 (1978) 49.

4. Jergil, B., Sommarin, M., Henriksson, T. and Schelin, C. In Krause, E.-G., Pinna, L. and Wollenberger, A., Eds., Cyclic Nucleotides and Protein Phosphorylation in Cell Regulation, Pergamon, Oxford 1979, p. 235.

5. Yamanura, H., Takeda, M., Kumon, A. and Nishizuka, Y. Biochem. Biophys. Res. Commun. $40(1970) 675$.

6. Chen, L.-J. and Walsh, D. A. Biochemistry 10 (1971) 3614.

7. Kleitke, B., Sydow, H. and Wollenberger, A. Acta Biol. Med. Germ. 35 (1976) K9.

8. Sankaran, K., Pawse, A. R. and Nadkarni, G. B. Biochim. Biophys. Acta 438 (1976) 412.

9. Henriksson, T. and Jergil, B. Biochim. Biophys. Acta 588 (1979) 380.

10. Takeda, M., Yamanura, $H$. and Ohga, $Y$. Biochem. Biophys. Res. Commun. 42 (1971) 103.

11. Kruh, J., Dastugue, B., Defer, N., Kamiyama, M. and Tichonicky, L. Biochimie 56 (1974) 995.

12. Blat, C. and Harel, L. Biochim. Biophys. Acta 173 (1969) 23.

13. Blat, C. and Harel, L. Biochim. Biophys. Acta $203(1970) 271$.

14. Shlatz, L. and Marinetti, G. V. Biochem. Biophys. Res. Commun. 45 (1971) 51.

15. Chang, K.-J., Marcus, N. A. and Cuatrecasas, P. J. Biol. Chem. 249 (1974) 6854.

16. Aronson, N. N. and Touster, O. Methods Enzymol. 31 (1974) 90.

17. Widnell, C. C. and Unkeless, J. C. Proc. Natl. Acad. Sci. U.S.A. 61 (1968) 1050.

18. Mosbach, K., Guilford, H., Ohlsson, R. and Scott, M. Biochem. J. 127 (1972) 625.

19. Shore, G. C. and Tata, J. R. J. Cell. Biol. 72 (1977) 714.

20. Hrycay, E.-G. and O'Brien, P. J. Arch. Biochem. Biophys. 160 (1974) 230.

21. Morré, D. J. Methods Enzymol. 22 (1971) 130.

22. Jergil, B. Eur. J. Biochem. 28 (1972) 546.

23. Jergil, B. and Ohlsson, R. Eur. J. Biochem. 46 (1974) 13.
24. Walsh, D. A., Ashby, C. D., Gonzalez, C., Calkins, D., Fisher, E. H. and Krebs, E. G. J. Biol. Chem. 246 (1971) 1977.

25. Lowry, O. H., Rosebrough, N. J., Farr, A. L. and Randall, R. J. Biol. Chem. 193 (1951) 265.

26. Neville, D. M., Jr. J. Biol. Chem. 246 (1971) 6238.

27. Corbin, J. D., Keely, S. L. and Park, C. R. J. Biol. Chem. 250 (1975) 218.

28. Azhar, S. and Menon, K. M. J. Eur. J. Biochem. 58 (1975) 105.

29. George, E. R., Balakir, R. A., Filburn, C. R. and Sacktor, B. Arch. Biochem. Biophys. 180 (1977) 429.

30. Higgins, J. A. and Evans, W. H. Biochem. J. 174 (1978) 563.

31. Losa, G. A., Weibel, E. R. and Bolender, R. P. J. Cell Biol. 78 (1978) 289.

32. Kang, E. S., Gates, R. E. and Farmer, D. M. Biochem. Biophys. Res. Commun. 83 (1978) 1561.

33. Ronquist, G. and Ågren, G. Acta Chem. Scand. B 28 (1974) 1169.

34. Gazitt, Y., Ohad, I. and Loyter, A. Biochim. Biophys. Acta 436 (1976) 1.

35. Rudolph, S. A. and Greengard, P. J. Biol. Chem. 249 (1974) 5684.

36. Mårdh, S. In Skou, J. C. and Norby, J. G., Eds., Na, K-ATPase. Structure and Kinetics, Academic, London 1979, p. 359.

Received August 25, 1980. 